\title{
Current nature and problems of agricultural land management in the Republic of Crimea
}

\author{
$E$ I Ergina ${ }^{1, *}, G E$ Tronza $^{1}, I M$ Shevchenko $^{1}, S M$ Ergin $^{1}$, and $I Y a$ Sidorenko $^{1}$ \\ ${ }^{1}$ V. I. Vernadsky Crimean Federal University, Republic of Crimea, Pr. Vernadsky, 4, 295007, \\ Simferopol, Russia
}

\begin{abstract}
The main problems of the nature and management of agricultural land under the conditions of modern soil management have been considered. Among the processes which cause soil structure decline on the Crimean peninsula, predominate: erosion, deflation, dehumification, secondary salinization and alkalinization of previously irrigated areas, overgrowing of agricultural land with shrubs and light forests, and some other processes leading to loss of soil fertility. Considerable attention has been paid to the problem of developing a system for soil resources monitoring. It has been noted that the main problems in the rational management of agricultural land in the region are: the imperfection of the regional monitoring system for the nature, conservation, management and protection of soil cover, and the lack of reliable and complete information on the nature of agricultural land.
\end{abstract}

\section{Introduction}

The uniqueness of the soil and climatic conditions of the Crimean peninsula determines the significant potential of land suitable for management in the agricultural industry. Currently, the development of agricultural production largely depends on the degree of consideration of environmental conditions. On the one hand, this includes the use of the ecological potential of the territory by plants in order to obtain the maximum amount of quality products incorporated in the genotype of the cultivated crop. On the other hand, agricultural production should fit as much as possible into the natural environment, thereby contributing to its rational management, optimization and protection.

The physico-geographical conditions of the Crimean peninsula, which caused the formation of diverse landscapes in a small area from the steppes of the hydromorphic landscape level to forests, within the foothills and mid-mountain landscape[1], have determined the formation of significant soil diversity on its territory [2]. Chernozems and their varieties with a high proportion of Kashtanozems Rendzic Leptosols and Cambisols dominate in the structure of the soil cover of the Republic of Crimea (Fig. 1).

\footnotetext{
*Corresponding author: ergina65@mail.ru
} 


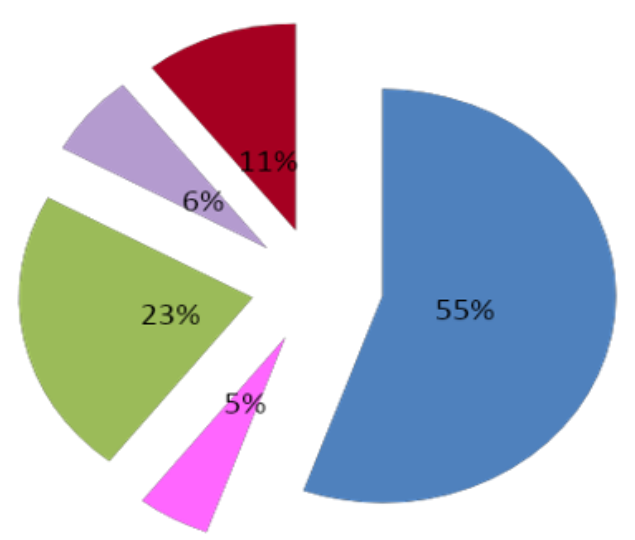

Fig. 1. The structure of the soil cover of agricultural land [3]. Legend: - Chernozems and their varieties; - Rendzic Leptosols; _ - Kashtanozems; _ - soils of mountainous areas; other types of soils.

Many scientists have paid considerable attention to the ecological state of the Crimean soils, to the study of their dynamics, to the evolution for the development of measures for the rational use of land at different periods. Among them Polovitsky I.Ya., Gusev P.G. [4], Dragan N.A. [5], Kizyakov Yu.E., Tronza G.E. [6], Tronza G.E. [7], Ergina E.I. [8-9], Ergina E.I., Tronza G.E. [10], Lisetskii et al. [11], Pashtetskiy V.S., et al., [12-13].

Currently, the development of urbanization and industrialization, the construction of roads, the creation of technical infrastructure have been causing significant damage to the agricultural lands of the region, which manifests itself in the form of soil degradation and land disturbance. The main negative processes are: erosion, deflation, secondary salinization and alkalinization of previously irrigated areas, overgrowing of agricultural land with shrubs and light forests, and other processes leading to the loss of soil fertility. Intensive anthropogenic and technogenic pressure, along with changes in the climatic system of the Crimean peninsula, have already led to the development of transformation processes in landscapes and agrolandscapes of the peninsula. The increase in air temperature, anomalies and precipitation regimes have already contributed to the desertification process, have increased the likelihood of extreme hydrometeorological phenomena, resulting in socio-economic risks of land management and development of agricultural sectors on the peninsula [14].

Sustainable development of the agricultural industry depends on many factors, such as the organization of production activities, the level of application of advanced technologies, market, social aspects, and others. But the basis for the sustainable development of agricultural production are land resources, in particular, the region's provision with fertile land.

\section{Materials and research methods}

In modern conditions of agricultural production on the territory of the Crimean peninsula, there is a tendency to deterioration and loss of fertility of agricultural land. This happens due to the imperfection of accounting, inventory and protection of land in this category. The solution of these issues - one of the priority tasks of socially sustainable development 
of both the Republic of Crimea and the Russian Federation as a whole. An empirical approach has been used while preparing this work, which in the framework of the article involves such techniques as observation, analysis, study and comparison.

The research materials were statistical data from the Ministry of Ecology and Natural Resources of the Republic of Crimea, the Federal State Registration, Cadastre and Cartography Service that are in the public access [3, 15], as well as stock and archive data from the Ministry of Agriculture and the Federal State Budgetary Institution "Crimean Agrochemical Service Center".

\section{The results of the study}

The geographical location and environmental conditions of the Crimean peninsula, along with the tourist and recreational potential, are favorable for the efficient management of agricultural production. Agriculture in the region is a fairly well developing sector of the economy. One of the main production areas in this area is crop production. This leads to a significant weight of the share of arable land in the structure of agricultural land of the Republic of Crimea - 70.9\% (Fig. 2). The main areas of arable land are concentrated in the steppe regions of the region. The soil cover of this territory is mainly represented by Kashtanozems and Chernozems having a number of regional features, as well as a strip of Rendzic Leptosols of the foothill steppe making up the lower zone of the vertical zones of the main ridge of the Crimean mountains. The clearly expressed vertical zoning of soils in the mountainous Crimea causes an inversion of soil zones in the plain [1,4-5]. In general, soils of good and satisfactory fertility levels prevail on the peninsula [5].

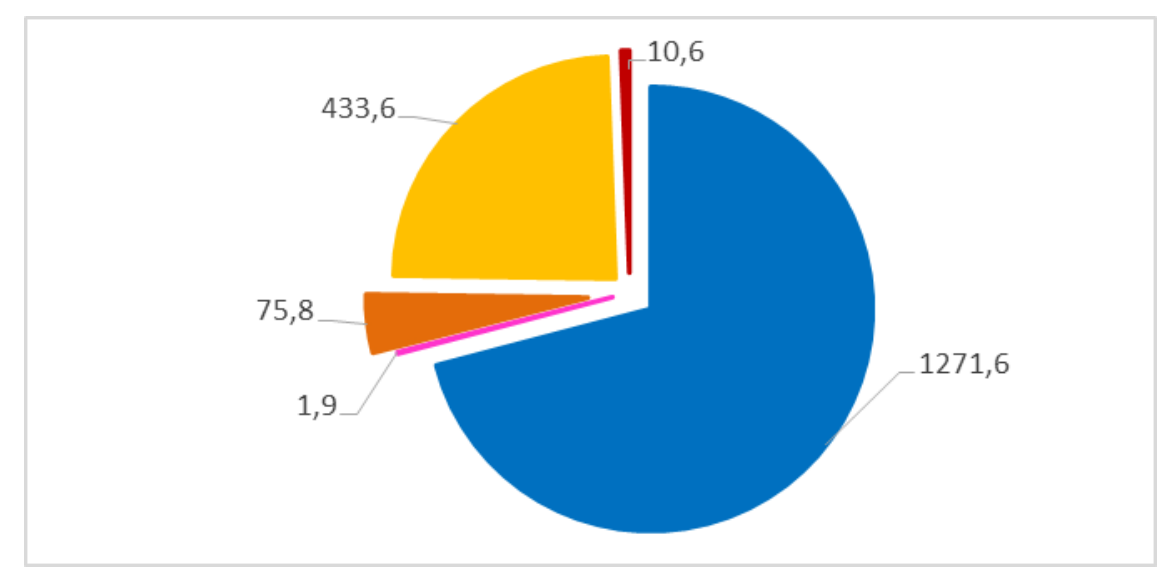

Fig. 2 The structure of agricultural land of the Republic of Crimea (thousand hectares) as of 01.01.2019 [3]. Legend: _ - arable land; _ _ - hayfields; _ - perennial plantings; pasture; fallow.

Despite the significant potential of agricultural land in the region, serious problems have steadily been growing related to the preservation of its quality and, in particular, of the potential soil fertility of agricultural land. Today, the main problems of the soil quality and soil cover disturbances are the following:

- destruction and replacement of natural landscapes with agrogenic and technogenic;

- increase of eroded land in the area in the structure of agricultural land;

- loss of soil itself as a result of mechanical disturbance of land as a result of construction work and mining. 
At the present stage of development of agricultural land management, the problem of increasing of erosion-hazardous areas of agricultural land has been acute not only in the Crimea and the Russian Federation, but also in general, throughout the world. In the report of the Food and Agriculture Organization of the United Nations (FAO), among 10 global soil problems, soil erosion comes first [16].

Intensive agricultural production in the region, manifested in the form of high plowing, use of steep slopes as part of arable land, insufficient afforestation and watering of arable land, excessive mechanical impact on soils, use of heavy agricultural machinery that destroys the natural structure and composition of the soil, degradation of natural fodder vegetation land, low culture of managing on the land have led to the loss of soil inherent ability of self-regulation and the spread of considerable areas of flushing, erosion and blowing the fertile layer as a result of water and wind erosion. Today, more than $70 \%$ of arable land on the peninsula is prone to erosion [17-19]. It should be noted that over the past 20 years in the Crimea there has been a clear tendency to increasing of the area of eroded agricultural land. The most intense erosion processes have taken place on the lands of Saksky, Razdolnensky, Simferopol and Belogorsky administrative regions. According to previous studies, the total area of agricultural land subject to deflation on the peninsula is $63.1 \%$, water erosion is 11.3 , and the combined effect of water and wind erosion is $2.7 \%$ (Table 1) [17]. The result of erosion, as it is known, is the deterioration of the physical, chemical and biological properties of soils. As a result of erosion, the content and reserves of humus, mobile forms of the basic elements of plant nutrition (N, P, K, etc.) reduce. The structural nature and composition worsen, porosity decreases, density increases, which leads to a decrease in water permeability, an increase in surface runoff, and a decrease in moisture capacity and moisture reserves available to plants. Given the scarcity of water resources on the peninsula, the loss of melt and rainwater due to erosion is extremely unfavorable. The demolition of the upper most humus and structured soil layer causes a decrease in the microbiological and enzymatic activity of soils. There are a lot of negative consequences of erosion processes in the soil. Ultimately, even a partial decrease in soil fertility leads to lower crop yields. The expansion of eroded land in the region is a negative trend for the efficient management of agricultural production.

Table 1. Area of Crimean agrolandscapes subject to erosion [17].

\begin{tabular}{|c|c|c|c|c|c|c|}
\hline \multirow{2}{*}{$\begin{array}{c}\text { Types of agricultural } \\
\text { land }\end{array}$} & \multicolumn{2}{|c|}{ Wind erosion } & \multicolumn{2}{c|}{ Water erosion } & \multicolumn{2}{c|}{$\begin{array}{c}\text { exposed to joint } \\
\text { exposure }\end{array}$} \\
\cline { 2 - 7 } & $\begin{array}{c}\text { Total } \\
\text { thousan } \\
\mathrm{d} \\
\text { hectares }\end{array}$ & $\begin{array}{c}\text { in\% to } \\
\text { the type } \\
\text { of land }\end{array}$ & $\begin{array}{c}\text { total } \\
\text { thousand } \\
\text { ha }\end{array}$ & $\begin{array}{c}\text { in\% to } \\
\text { the type } \\
\text { of land }\end{array}$ & $\begin{array}{c}\text { total } \\
\text { thousand } \\
\text { ha }\end{array}$ & $\begin{array}{c}\text { in\% to the } \\
\text { type of } \\
\text { land }\end{array}$ \\
\hline Arable land & 823.2 & 66.0 & 96.0 & 7.6 & 31.8 & 2.5 \\
\hline Perennial plantings & 46.8 & 37.4 & 10.8 & 8.6 & 0.3 & 0.2 \\
\hline Pastures & 247.2 & 62,2 & 92.5 & 23.3 & 15.8 & 4.0 \\
\hline Total agricultural land & 1117.2 & 63.1 & 199.3 & 11.3 & 47.9 & 2.7 \\
\hline
\end{tabular}

An increase in pasture load along with the high plowing of the territory is considered to be among the reasons for the activation of erosion processes. But in the trend in modern dynamics of physical, geographical and environmental processes in agrolandscapes [20-21], the assertion that sheep grazing on pastures is becoming one of the main reasons for significant soil erosion and land degradation of the Foothills of the Crimean mountains , can be ambiguous and may require detailed studies. The main reason for the degradation of the soil cover of pastures of the Foothills is the abandonment of most pastures in the region due to the privatization of fixed assets in agricultural production, the lack of necessary agrotechnical and land reclamation measures; destruction of forest shelter belts preventing wind erosion [22]. 
The number of the degraded agricultural lands includes soils that are naturally saline and alkali, waterlogged, boggy. According to "the Crimean" Agrochemical Service Center", about $25 \%$ of the arable land in the Crimea is saline and alkali to varying degrees. Since 1963, a significant part of the soils of the steppe Crimea had been irrigated by the waters of the North Crimean Canal and had been used in rice-alfalfa agrocenoses. About $50 \%$ of the soil cover structure of the rice irrigation systems of the Crimea (15 thousand ha) composed of meadow Solonetzes [6-7]. Since 2014, in connection with the accession of Crimea to Russia, the flow of water into the North Crimean Canal has stopped. Currently, there are no statistics on the processes of secondary salinization and alkalinization of soils, but studies of a number of scientists indicate the initial stage of these processes in previously irrigated areas [23-24]. The problem of reclamation of saline and alkaline soils in the region has practically not been studied, which in the near future can affect the productivity of both field crops and perennial plantings.

Large areas of the Republic of Crimea are represented by Chernozems low humus and Kashtanozems, in which the content of humus averages from 2.5 to $3 \%$. And yet, despite this feature of soils, it is necessary to note the regions with the largest areas of low humus soils. So in the Bakhchisaray, Dzhankoy, Krasnoperekopsky and Leninsky districts, areas with low and lower content of organic material account for more than $70 \%$ of the entire surveyed area. In other areas, the percentage of areas with low and lower humus content ranges from 9.8 to $67.9 \%$. Along with the problem of the quality state of agricultural land in the region, the problem of its depletion has been no less acute. A significant proportion of agricultural land has currently been owned by individuals, as evidences the statistics from the Federal Service for State Registration, Cadastre and Cartography (Fig. 3).

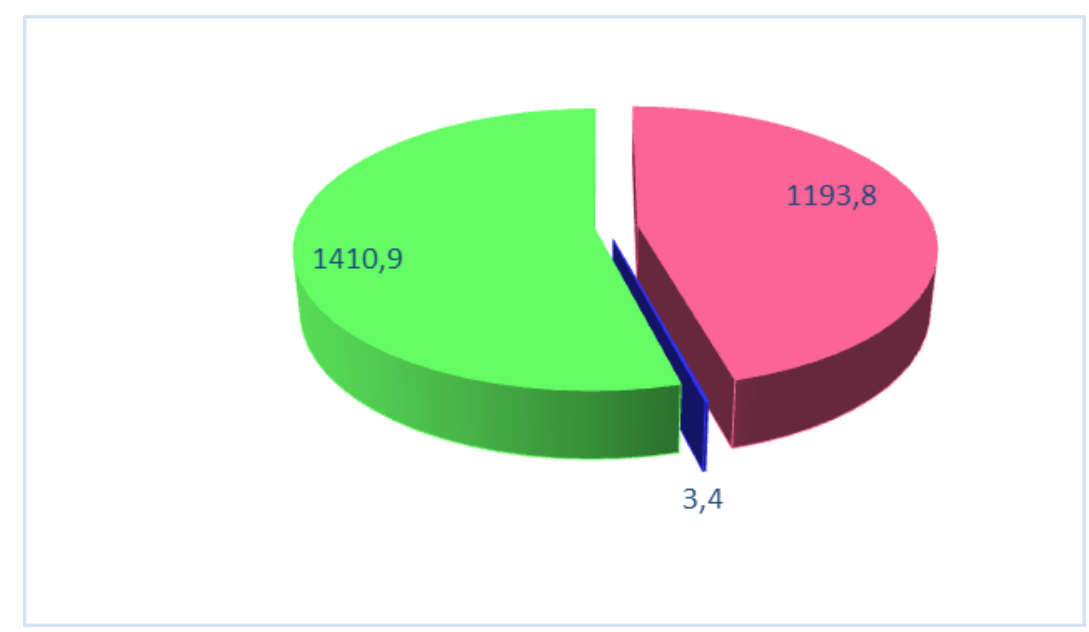

Fig. 3. Distribution of land of the Republic of Crimea by ownership as for 01.01. 2019 (thousand ha) [15]. Legend: - owned by citizens; - owned by legal entities; _ - in state and municipal ownership.

The owners of land plots received as a result of the re-plowing of the lands of former agricultural enterprises mainly practice cultivation of one crop. Despite the use of significant doses of fertilizers, the result of monoculture is a deterioration in the quality of the soil and a violation of the ecological balance in agrolandscapes. A significant part of the plowed lands is now either abandoned or used for other purposes. 


\section{Discussions}

According to the authors, the main problem in the field of rational management of agricultural land in the region is the imperfection of the regional monitoring system for the nature, conservation ,management and protection of soil cover, the lack of reliable and complete information about the nature of agricultural land. In order to obtain the most reliable natural-ecological materials, the authors recommend the improvement of the geographic information system, as well as the use of a computer-aided planning system (CAPS), an automated design system (ADS), which will prevent irreversible environmental consequences, including soil degradation [25-26]. The geographic information system should have a distributed structure, which will be represented by central and territorial offices. The central office should be represented by the Ministry of Agriculture of the Republic of Crimea, and the territorial ones - by departments in the municipal authorities. The main functions of such systems should be: maintaining a register of data on agricultural crops, the location of cultivated areas, the nature of crops; space monitoring of sown areas; monitoring of unused lands and monitoring the parameters of soil fertility and the development of processes of their degradation; formation of statistical and user reports and thematic maps of agricultural lands [25]. The use of geo-information technologies will make it possible to maintain high-quality records of objects of the agricultural industry, automate monitoring of the current activities of agricultural enterprises, study the processes of controlling the fertility of arable land and prevent degradation processes of soils, as well as to collect materials for an inventory of agricultural land, which will provide a solution to the main problems of the Republic of Crimea in the rational use of land.

To adapt all the soil information, including for the purpose of cadastral assessment of the quality of agricultural land, it is necessary to take a number of organizational and methodological measures: to create the Department of the Unified State Register of Soil Resources (DUSRSR) in the Republic of Crimea on the basis of the methodological platform of the USRSR of Russia. The Crimean Regional Register of Soil Resources will include complete unified digital information on the diversity of soils of the Crimean peninsula. The technological platform of the register should focus on assessing the suitability of soils for agricultural production, cadastral work, monitoring degradation under conditions of technogenesis and global climate change, which opens up new possibilities for the formation of a state policy for the management and protection of soils, assessing the quality of soils, the justified purpose of land payments, and others.

The methodological basis for the creation of the Unified State Register of Land Register in the Crimea should be the Unified State Register of Soil Resources of Russia [27-28]. The creation of the Regional Register requires coordination with the Ministry of Property and Land Relations of the Republic of Crimea, the Ministry of Ecology and Natural Resources of the Republic of Crimea, the Research and Design Institute for Land Management, Cadastre and Real Estate Appraisal, The "Crimean Agrochemical Service Center" and other institutions in the Crimea, which contain a unique cartographic, informational and analytical database on the nature and dynamics of the soil properties of the Crimea, which needs to be systematized, unified, converted into electronic form. But, unfortunately, today we encounter a lack of understanding of the role of the Unified Land Register and the Register of the Crimean Soil Resources in the modern practice of the management, protection and regulation of land relations by the executive and legislative authorities of the Crimea. And, as a result, the lack of organizational, scientific and methodological measures to create a USRSR on the territory of the Crimean peninsula. 


\section{Conclusion}

An analysis of the current management of agricultural land has shown, that at present, on the territory of the Crimean peninsula, a progressive negative tendency has been observed to deteriorate the quality of land in the characterized territory. The main negative processes are: erosion, deflation, secondary salinization and alkalinization of previously irrigated areas, overgrowing of agricultural land with shrubs and light forests, and other processes leading to the loss of soil fertility.

The main problem in the field of rational management of agricultural land in the region is the imperfection of the regional monitoring system for the nature, conservation, management and protection of soil cover, the lack of reliable and complete information on the management of agricultural land.

The solution of the problems of rational management of agricultural land, as well as maintaining of agrolandscapes in stable equilibrium with the external conditions in the Republic of Crimea, is possible by developing a system of measures to organize a system for monitoring soils and lands with geo-information systems use and creation of a Unified State Register of Soil Resources of the Republic of Crimea.

\section{References}

1. Modern Landscapes of Crimea and Adjacent Water Areas ed E A Pozachenyuk (Simferopol: Business Inform Publishing House) p 672

2. Dragan N A 2005 Crimean soil cover evolution as a result of ecogeodynamic processes Geopolitics and ecogeodynamics of regions issue 1 59-71

3. On the state and protection of the environment in the Republic of Crimea in 20162017 Report of the Ministry of Ecology and Natural Resources of the Republic of Crimea (Izhevsk: LLC Print) p 300

4. Polovitsky I Ya and Gusev P G 1987 Soils of the Crimea and Increase of their Fertility (Simferopol: Publishing House Tavria) p 152

5. Dragan N A 2008 Agroecological state of land resources of Crimea Papers of Nikitsky Botanical Garden 130 55-61

6. Kizyakov Yu E and Tronza G E 2002 Salt profiles of solonetzes of meadow Crimean Black Sea coast and their transformation in rice crop rotation News of Kharkivsky NAU im. V V Dokuchaev issue 1 144-149

7. Tronza $G E 2002$ Salt regime of solonetzes of meadow Crimean Black Sea coast developed under rice culture Transactions of Crimean GATU: Agricultural sciences Simferopol issue 91 242-247

8. Ergina E I 2017 Spatial-temporal Patterns of Modern Soil Formation processes on the Crimean Peninsula (Simferopol: LLC Publishing House Printing House Arial) p 220

9. Ergina E I 2017 Modeling of the Development of Humus Horizons in Soils of Crimea Eurasian Soil Science 50(1) 14-19

10. Ergina E I and Tronza G E 2016 The modern soil-ecological state of the Crimean peninsula Scientific notes of the VI Vernadsky Crimean Federal University Geography Geology 2(68) No 3 196-203

11. Lisetskii F N, Rodionova M E, Terekhin E A, Stolba V F and Ergina E I 2013 Post- 
agrogenic evolution of soils in ancient greek land use areas in the Herakleian peninsula, southwestern Crimea The Holocene 23(4) 504-514

12. Pashtetskiy V S, Zhenchenko K G and Prikhodko A V 2015 Influence of adverse natural phenomena on soil degradation and the agro-industrial complex of Crimea Bulletin of the Soil Institute named after V V Dokuchaev issue 77 94-105

13. Pashtetskiy V S, Radchenko L A and Zhenchenko K G 2015 Humus conservation in Crimean soils is the main factor in increasing fertility Agrarian Bulletin of the Urals No 5(135) 24-27

14. Ergina E I and Zhuk V O 2019 Spatiotemporal Variability of the Climate and Dangerous Hydrometeorological Phenomena on the Crimean Peninsula Russian Meteorology and Hydrology 44(7) 494-500

15. Rostreestr Information on the availability and distribution of land in the Russian Federation (Electronic Materials) access mode https://rosreestr.ru

16. FAO Soils are endangered, but the degradation can be rolled back (Electronic Materials) access mode http://www.fao.org/news

17. Ergina E I, Gorbunov R V and Scherbina A D 2018 Geographic Analysis of Permissible Soil Erosion Standards in the Agrolandscapes of the Crimean peninsula (Simferopol: LLC Publishing House Printing House Arial) p 180

18. E I, Gorbunov R V and Stashkina E F 2019 Maximum Humus Horizon Thickness as a Criterion for Identifying Standard Soils in the Crimean Plain Russian Agricultural Sciences 45 453-457

19. Ergina E I, Gorbunov R V and Scherbina A D 2018 Soil Standards and Rare Soils of the Plain Crimea (Simferopol: LLC Publishing House Printing House Arial) 168

20. Pasynkov A A, Ergina E I and Zhuk V O 2020 Technogenesis and Geochemical Features of the Crimean Soils and Landscapes Int. sc. and tech. conf. Earth Science IOP Conf. Series : Earth and Environmental Science vol 459/2 022022 (Vladivostok: IOP Publishing) pp 2-7

21. Ergina E I, Ergin S M and Sidorenko I Ya 2020 Ecological and Economic Evaluation of the Disturbed Lands Recultivation Projects in the Republic of Crimea Int. sc. and tech. conf. Earth Science IOP Conf. Series: Earth and Environmental Science vol 459/2 022021 (Vladivostok) pp 2-7

22. Ergina E I, Adamen F F and Sidorenko E A 2018 Optimization of the use of erosionhazardous pasture agrolandscapes in the foothill Crimea Bulletin of Agricultural Science of Tauris No 14(177) 17-30

23. Khitrov N B, Klimenko O E et al. 2017 Long-term consequences of soil irrigation with water from the North Crimean Canal in gardens Taurian Bulletin of Agrarian Science No 1(9) 87-98

24. Chizhikova N P, Khitrov N P and Tronza G E 2017 Mineralogical composition of particle-size fractions of solonetzes from the north Crimean lowland Eurasian soil science 50 No 12 1468-82

25. Yunchik Yu A and Tronza G E 2019 The current state and problems of sustainable development of the agro-industrial complex of the Republic of Crimea Collection of 
works of the IV Int. sc. and pract. conf. Economic and mathematical methods for analyzing the activities of agricultural enterprise (Saratov: Saratov State Agrarian University Publishing House LLC TseSain) pp 467-471

26. Artemova E A and Tronza G E 2020 The current state of the agricultural industry and the problems of organizing the rational use of agricultural land of the Leninsky district of the Republic of Crimea Collection of works on the materials of the II All-Russian scientific-practical conference Modern problems and prospects for the development of land and property relations (Krasnodar: LLC Print-Terra) pp 564-569

27. The Unified State Register of Soil Resources of Russia Version 1.0. 2014 ed. Ivanov A L and Shoba S A (Moscow: Soil Institute of V V Dokuchaev Russian Agricultural Academy) p 768

28. Ergin S M, Ergina E I, Sidorenko I Ya and Shamileva E E 2019 Problematic aspects of the development of a competitive environment in the production of construction materials in the Crimea Int. sc. conf. CATPID 2019 vol 698 (Kislovodsk: Published under licence by IOP Publishing Ltd.) pp 2-6 